\title{
The Optimization of Matrix Preparation Process and Performance Testing for Molten Carbonate Fuel Cell
}

\author{
Jian Cheng, ${ }^{1}$ Liejin Guo, ${ }^{1}$ Shisen $\mathrm{Xu},{ }^{2}$ and Ruiyun Zhang ${ }^{2}$ \\ ${ }^{1}$ State Key Laboratory of Multiphase Flow in Power Engineering, Xian Jiaotong University, Xian 710049, China \\ ${ }^{2}$ Huaneng Clean Energy Research Institute, Beijing 100098, China \\ Correspondence should be addressed to Jian Cheng; chengjian@hnceri.com
}

Received 27 February 2014; Accepted 26 March 2014; Published 23 April 2014

Academic Editor: Yixiang Shi

Copyright (c) 2014 Jian Cheng et al. This is an open access article distributed under the Creative Commons Attribution License, which permits unrestricted use, distribution, and reproduction in any medium, provided the original work is properly cited.

\begin{abstract}
A key component in the molten carbonate fuel cell (MCFC) is electrolyte matrix, which provides both ionic conduction and gas sealing. The aim of this work is to investigate the effects of selected operating conditions on the performance of the matrix preparation. Slurries were prepared to produce matrices by the technique of tape casting. The characteristics of the slurries and matrices were examined by laser particle size analyzer, scanning electron microscopy, and BET surface area analyzer. The testing results revealed that a slurry composition with $40 \mathrm{wt} . \%$ lithium aluminate was the optimal formulation to produce a good matrix with a pore size distribution of $0.1-0.4 \mu \mathrm{m}$ and porosity of $50 \mathrm{vol} . \%$. Coarse and fine $\mathrm{LiAlO}_{2}$ particles were added in the matrix slurry to enhance the mechanical strength. Several green sheets were heated and pressed to enhance the bulk density to get a dense matrix of MCFC. Finally, a single MCFC was assembled and tested. The testing results showed the matrix with $40 \%$ solid loading gave the maximum discharge current of $20 \mathrm{~A}$ at $0.56 \mathrm{~V}$.
\end{abstract}

\section{Introduction}

The electrolyte matrix is a key component in MCFC [1], which provides both ionic conduction and gas sealing. $\mathrm{LiAlO}_{2}$ powder is typically used as material for electrolyte matrices. The matrix in MCFC must fulfill certain conditions such as (1) free crack, free big pore, and good mechanical strength; (2) being full of molten carbonate and perfect for keeping the carbonate [2]; (3) good ionic conductivity; (4) porosity in the range of $40-70 \%$ [3].

MCFC matrices are usually fabricated by tape casting. Slurry preparation is the most critical step in matrix tape casting. $\mathrm{LiAlO}_{2}$ powder, organic binder, plasticizer, dispersant, and other additives are added into a kind of solvent and mixed with a ball mill to obtain uniform and stable slurry with certain fluidity. The selection of $\mathrm{LiAlO}_{2}$ powder particle size, solvent, dispersant, binder, and plasticizer is very important to the process of tape casting and directly affects the performance of tape casting slurry, thus the performance of green sheets, and eventually the performance of hotpressed matrices. Lee et al. [1] studied the $\mathrm{Al}$ reinforced matrix to improve its thermal stability. Batra et al. [4] prepared an alpha lithium aluminate matrix and described the characteristics of the matrix. The current development efforts focus mainly on optimizing the matrix structure and performance. So far, no systematic analysis related to the good matrix preparation process was made.

In order to investigate the effects of preparation conditions on the performance of electrolyte matrix, in this study, ceramic slurries with different weight ratios of $\mathrm{LiAlO}_{2}$ solid loading to the organic compounds were prepared to produce matrices with the technique of tape casting. The characteristics of the slurries and matrices were examined by laser particle size analyzer (S3500, Microtrac, USA), scanning electron microscopy (JSM-6010LV, JEOL, Japan), and BET surface area analyzer (ASAP 2020, Micromeritics, USA). An optimal matrix was prepared, and its performance was tested on gas crossover in the matrix and by discharge of MCFC under its operating conditions.

\section{Experimental Method}

2.1. Matrix Fabrication. The $\alpha-\mathrm{LiAlO}_{2}$ and $\gamma-\mathrm{LiAlO}_{2}(1: 1$ molar ratio) [5] powders were used as the solid constituent 
TABLE 1: Tape casting slurry composition of the matrix (wt. \%).

\begin{tabular}{lccccccc}
\hline Sample name & Solid & Solvent & Binder & Plasticizer & Dispersant & $\mathrm{Defoamer}_{2}$ & $\mathrm{Al}_{2} \mathrm{O}_{3}$ fiber \\
\hline a & 25 & 59 & 8 & 6 & 1.2 & 0.6 & 0.2 \\
b & 30 & 52 & 9 & 7 & 1.2 & 0.6 & 0.2 \\
c & 35 & 43 & 12 & 9 & 1.3 & 0.6 & 0.1 \\
d & 40 & 36 & 13 & 9 & 1.3 & 0.6 \\
\hline
\end{tabular}

of MCFC matrix. The $\alpha-\mathrm{LiAlO}_{2}$ and $\gamma-\mathrm{LiAlO}_{2}$ powders were made from boehmite reacting with $\mathrm{Li}_{2} \mathrm{CO}_{3}$ and $\mathrm{LiOH}$, respectively. The mixture of cyclohexanone and butyl alcohol (1:1 volume ratio) was used as the organic solvent. Polyvinylbutyral (PVB) was used as a binder. In the additives, polyethylene glycol was used as a plasticizer, triolein as a dispersant, silicone oil as a defoamer, and $\mathrm{Al}_{2} \mathrm{O}_{3}$ fiber as reinforced material. The slurry composition is given in Table 1.

The ratio of binder, solvent, plasticizer, dispersant, and $\mathrm{LiAlO}_{2}$ powder in the slurry was varied to obtain $\mathrm{LiAlO}_{2}$ powder loading in the range of 25-40 wt.\%. The slurry was prepared by ball milling of $\mathrm{LiAlO}_{2}$ powder for $10 \mathrm{~h}$ at speed of $350 \mathrm{rpm}$ in the solvent which contained the dispersant. Then the binder (PVB) and plasticizer were put into the mixture and ball mill for $5 \mathrm{~h}$. Subsequently defoamer and $\mathrm{Al}_{2} \mathrm{O}_{3}$ fiber were added into ball milling for another $2 \mathrm{~h}$. The slurry was filtered and vacuumed to remove bubbles. Green sheet of $10 \mathrm{~cm} \times 10 \mathrm{~cm}$ dimension was prepared by tape casting on a smooth glass surface. To obtain a good matrix for cell testing, $3-5$ pieces of green sheet were heated at $80^{\circ} \mathrm{C}$ and pressed to form one matrix under the pressure of $6 \mathrm{MPa}$. A flow chart [6] of the overall matrix preparation processes was presented in Figure 1.

2.2. Characterization. A laser particle size analyzer was used to measure the $\mathrm{LiAlO}_{2}$ particulate size distribution in different kinds of slurries mentioned above. Scanning electron microscopy was employed to study the morphology of the green sheet. BET surface area analyzer was used to examine the porosity and the pore size distribution of matrix after organic ingredients burned out.

2.3. Matrix Performance Testing. To evaluate the matrix performance for gas sealing, a single MCFC was assembled. Testing was conducted with an $11 \mathrm{~cm} \times 11 \mathrm{~cm}$ cell which had an electrochemical active area of $10 \mathrm{~cm} \times 10 \mathrm{~cm}$ [4]. The anode and cathode were made of nickel carbonyl and prepared by the technique of pasting slurry. They had typical porosity of $60 \mathrm{vol} . \%-70 \mathrm{vol} . \%$ and pore size in range of $5-10 \mu \mathrm{m}$ [7]. The matrix was prepared by several green sheets, which were produced with the slurry of $40 \mathrm{wt} . \% \mathrm{LiAlO}_{2}$ powder loading. The carbonate electrolyte was prepared by $\mathrm{Li}_{2} \mathrm{CO}_{3}$ and $\mathrm{K}_{2} \mathrm{CO}_{3}$ with molar ratio of 62 to 38 [8]. The optimal matrix and two carbonate green sheets were stacked as a sandwich. Stainless steel end plates and the matrix with the carbonate sheets were assembled into a single cell. The matrix and the electrolyte sheets were in situ sintered. The performance of

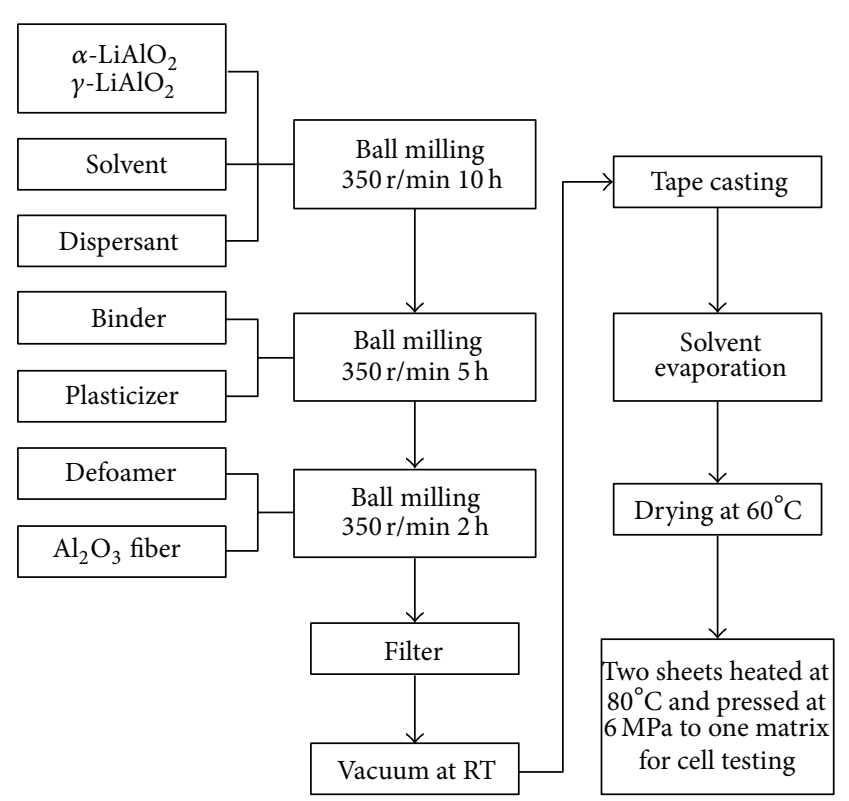

FIGURE 1: Flow chart of overall matrix preparation processes.

the unit cell was tested with SUN-FEL10A electronic load (Dalian Sunrise Power Limited-Liability Company).

\section{Results and Discussion}

3.1. Slurry Characterization. The matrix is an important component in MCFC; every aspect of its production could influence the final performance of the cell. The pore size distribution of the matrix was determined by the particle size of $\mathrm{LiAlO}_{2}$ and the organic ingredients in the slurry. According to the Yong-Laplace equation [3]

$$
P=\frac{2 \delta \cos \theta}{r}
$$

$\delta$, coefficient of surface tension of the electrolyte, is $0.198 \mathrm{NM}^{-1}$ and $\theta$, contact angle between the matrix and the electrolyte, is $\theta=0^{\circ}$.

It could be seen from (1) that the smaller the pore radius $r$ is in the matrix, the higher the penetrating pressure of matrix $P$ is. If the average radius of micropores in the matrix was less than $3.96 \mu \mathrm{m}$ [9], the matrix can be able to endure a pressure of $10^{5} \mathrm{~Pa}$ between anode and cathode. The $\mathrm{LiAlO}_{2}$ powder in the slurry can be small enough to ensure the radius of micropores in the matrix is less than $3.96 \mu \mathrm{m}$. It was generally believed that the optimum range of the ceramic particle size 


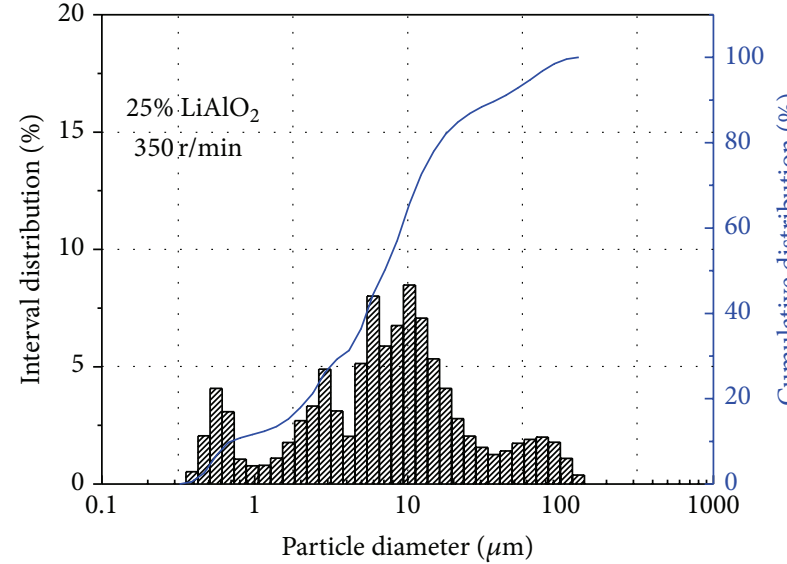

(a)

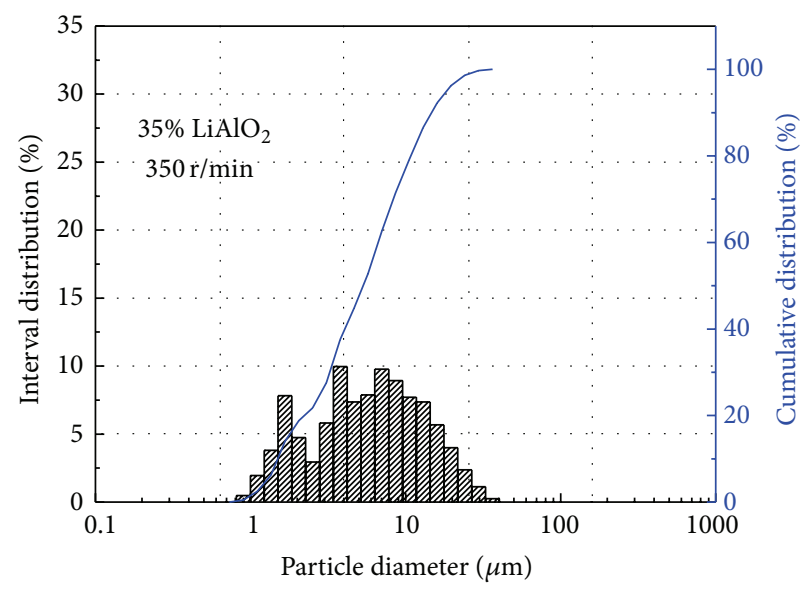

(c)

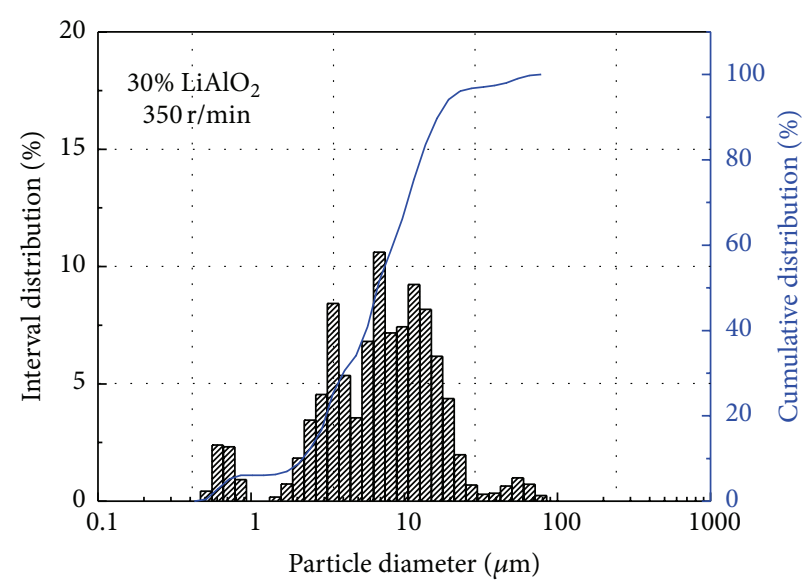

(b)

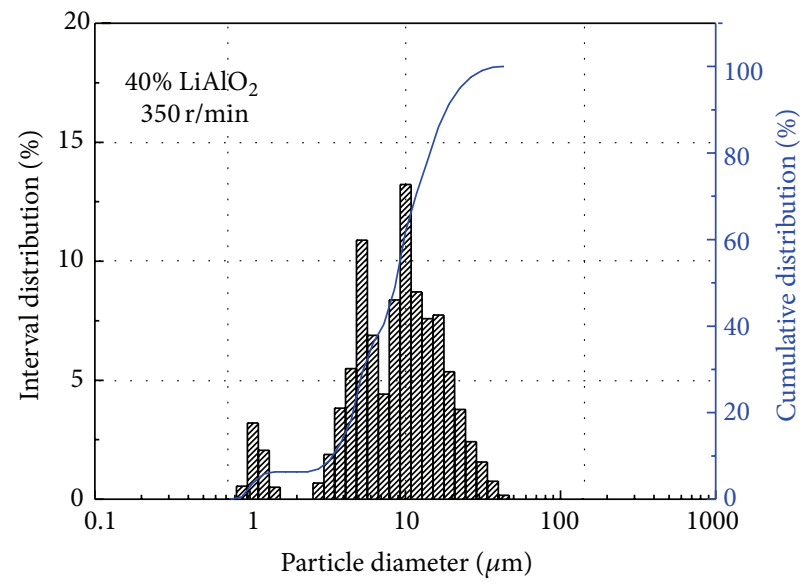

(d)

FIGURE 2: Particle analysis of slurries with different $\mathrm{LiAlO}_{2}$ solid loading for milling time $17 \mathrm{~h}$ at milling speed $350 \mathrm{rpm}$. (a) $25 \%$, (b) $30 \%$, (c) $35 \%$, and (d) $40 \% \mathrm{LiAlO}_{2}$ solid loading.

is in the range of $1-4 \mu \mathrm{m}[10]$ and the specific surface area is in the range of $2-5 \mathrm{~m}^{2} / \mathrm{g}[11]$.

The mill speed and milling time had a significant impact on the distribution of powder particle size. The cumulative distribution of the powder particles of the same diameter increased rapidly while the speed increased, but too high speed could accelerate the wear of the milling balls. With the increasing of milling time, the powder particle size decreased gradually, the specific surface area of the powder particles increased gradually, and the surface energy and surface activity of the powder particles increase and thus cause agglomeration, which extends the milling time again and makes the cumulative distribution of the powder particles of the same diameter drop slowly [12].

The mass fraction of the $\mathrm{LiAlO}_{2}$ powder in the slurry directly affects the rheology and particle density of the slurry. The lower the mass fraction was, the better the rheology was. Lower mass fraction is conducive to the improvement of milling efficiency. But too low mass fraction could reduce the collision of the powder particles with the milling media.

Particle size distributions in the slurries with different constituents mentioned above were shown in Figure 2.
It could be seen from Figure 2 that when the speed of ball milling was at $350 \mathrm{rpm}$, the average size of the particles in the four samples shown in the Figure 2 was larger than $3.96 \mu \mathrm{m}$. The lower the solid content of the slurry was, the wider the $\mathrm{LiAlO}_{2}$ particle size distribution was. However the $\mathrm{LiAlO}_{2}$ particle size distribution became narrower and the average particle size became smaller when the solid content increased. A possible explanation for this phenomenon could be that the collision opportunity for $\mathrm{LiAlO}_{2}$ particles and grinding ball increased in a viscous liquid. According to the trend mentioned above, when milling time and milling speed increased, the average particle size of $\mathrm{LiAlO}_{2}$ particles in the slurry became smaller and particle size distribution became narrower.

Figures 3 and 4 showed that particle size distributions of the slurries with $35 \%$ and $40 \%$ solid content, respectively, with milling speed increased to $450 \mathrm{rpm}$ and the milling time increased to $24 \mathrm{~h}$. As was evident in Figures 3 and 4, the $\mathrm{LiAlO}_{2}$ particle average diameter decreased to $1.67 \mu \mathrm{m}$ and $1.76 \mu \mathrm{m}$, respectively, and about $90 \%$ particle size was less than $4.0 \mu \mathrm{m}$. As increasing the speed and the milling time in the initial ball milling stage had a possible effect on the 


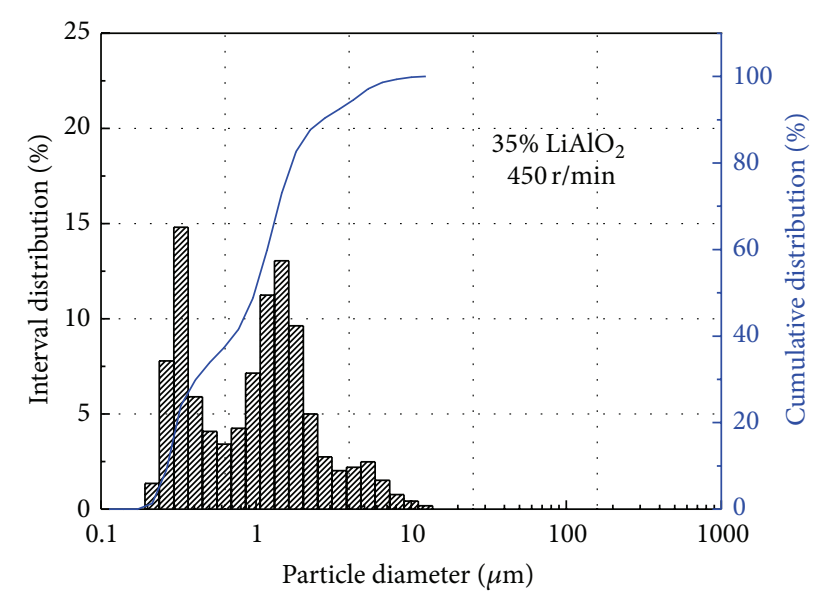

FIGURE 3: Particle analysis of the slurry with $35 \% \mathrm{LiAlO}_{2}$ solid loading for milling time $24 \mathrm{~h}$ and at milling speed $450 \mathrm{rpm}$.

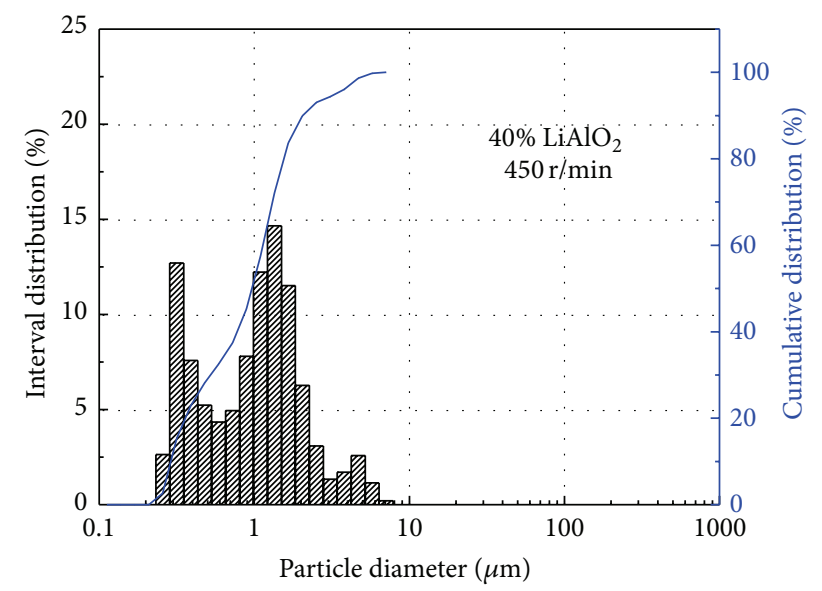

Figure 4: Particle analysis of the slurry with $40 \% \mathrm{LiAlO}_{2}$ solid loading for milling time $24 \mathrm{~h}$ and at milling speed $450 \mathrm{rpm}$.

particle size distribution in the slurry, one piece of green sheet could not prevent $0.1 \mathrm{MPa}$ pressure difference between anode and cathode. Hot pressing several green sheets into one dense matrix was an effective method to reduce the defect and the big pore size in the matrix.

3.2. The Contents of Organic Compounds. The organic solvents could wet $\mathrm{LiAlO}_{2}$ powder particles better than waterbased solvents and prepare the slurry with lower viscosity and shorter drying time because of its good volatility [13]. The binder could wrap the powder particles, self-cure to form a surface to produce a strong three-dimensionally interconnected resin frame. It could increase the strength and toughness of green sheet [14]. The binder content in the slurry could increase with the content of $\mathrm{LiAlO}_{2}$ powder. The plasticizer in the slurry could reduce the plastic limit temperature of the binder below room temperature, so that the binder had good fluidity and did not condense at room temperature [15]. The binder and the plasticizer were used together in the preparation of the slurry [16].

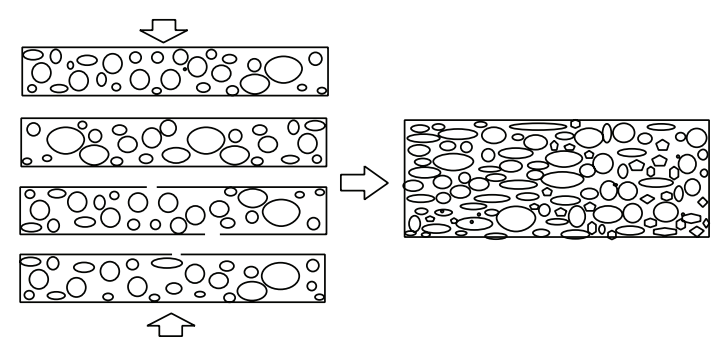

FIGURE 5: Pores brought about piling up of different particles resulting in pressing.

An appropriate amount of plasticizer micromolecules was inserted in the polymer chains of the binder to increase the long-chain distance. It played a lubricating role and reduced the viscosity. The dispersant in the slurry could be adsorbed on the particle surface to prevent the powder particles from agglomerating. The dispersant reduced the viscosity of the slurry and improved its rheology mainly by increasing the repulsive potential energy or lowering the gravitational potential energy among the particles.

In the milling process, the binder and the dispersant could absorb and wrap the $\mathrm{LiAlO}_{2}$ powder particles competitively; they affect the distribution uniformity and rheology of the particles in the slurry [17]. Therefore, the organic solvent, $\mathrm{LiAlO}_{2}$ powder, and dispersant should be added firstly during the preparation of the slurry to wet the $\mathrm{LiAlO}_{2}$ powder and break the aggregates via ball milling. In the mixing process, the dispersant was adsorbed on the $\mathrm{LiAlO}_{2}$ powder particles to form a film, which prevents the particles from reaggregating. This caused the $\mathrm{LiAlO}_{2}$ powder particles suspended in the slurry, as was a necessary prerequisite to play the best effect of the dispersant. The binder and the plasticizer were added after 10 hours of ball milling. Compound stability with the dispersant after being stirred was generated to maintain the $\mathrm{LiAlO}_{2}$ powder particles in a suspended state. Finally, defoamer was added to enlarge the air bubbles in the slurry to the extent of rupture in the milling process. Alumina fibers were added to improve the mechanical strength of the matrices.

As presented in Table 1, the weight percentage of the organic compounds decreased with the increasing of $\mathrm{LiAlO}_{2}$ solid loading. It indicated that the particles were less separated in the slurries. The contents of the organic compounds were decreased in the distances between $\mathrm{LiAlO}_{2}$ particles in the matrices with the increasing of $\mathrm{LiAlO}_{2}$ solid loading.

3.3. The Natural Piling Up of $\mathrm{LiAlO}_{2}$ Particles. The mixture of $\gamma-\mathrm{LiAlO}_{2}$ and $\alpha-\mathrm{LiAlO}_{2}$ could be used in preparing matrix due to its property of keeping the initial phases composition in MCFC environment. Various size $\mathrm{LiAlO}_{2}$ particles were piled up to produce good mechanical strength for matrix. The $\gamma-\mathrm{LiAlO}_{2}$ powders were synthesized by boehmite, which could be used as coarse powders. $\alpha-\mathrm{LiAlO}_{2}$ was used as a fine powder in the matrix slurry production. 2-10 wt.\% of fine powder was added into the organic compounds at the beginning of ball milling processes, and $10-15 \mathrm{wt} . \%$ coarse 


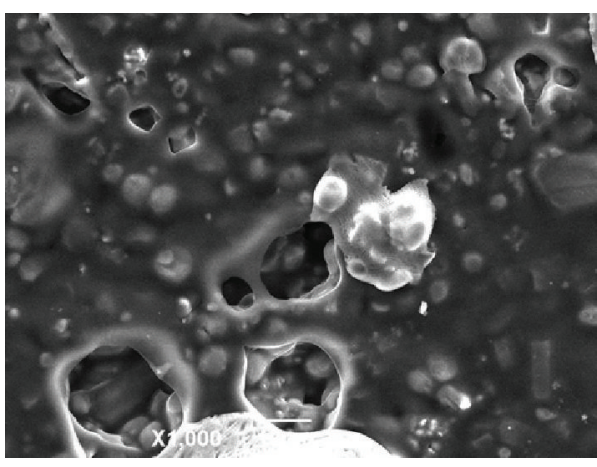

(a)

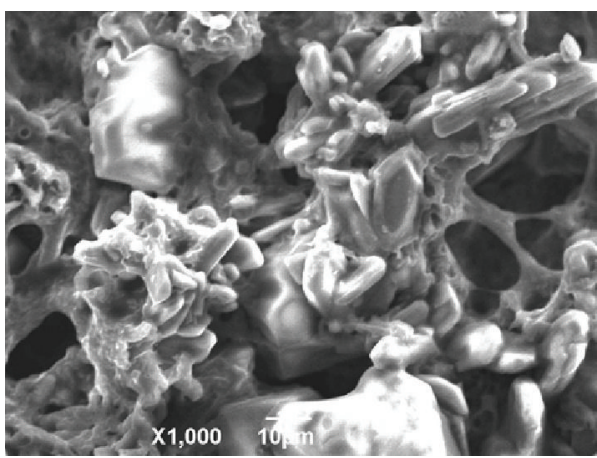

(c)

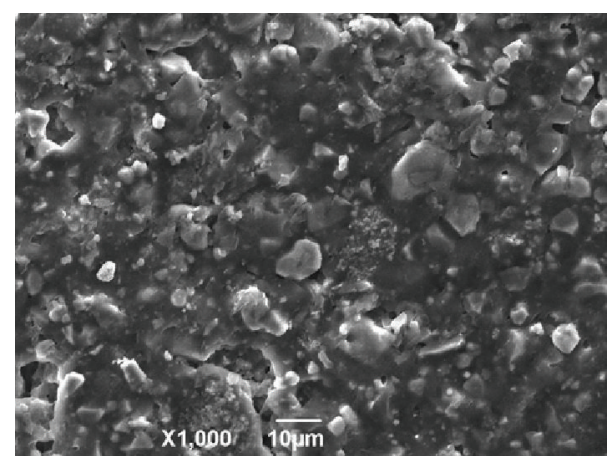

(b)

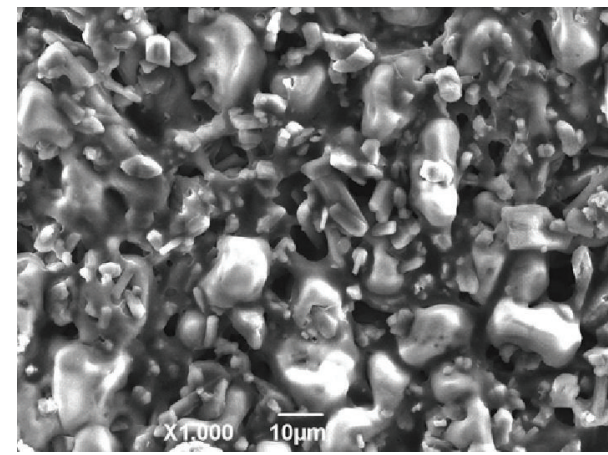

(d)

FIGURE 6: Morphologies of the green sheets with (a) 25\%, (b) 30\%, (c) 35\%, and (d) $40 \% \mathrm{LiAlO}_{2}$ solid loading.

powder was added to the compounds in last stage of ball milling. Coarse powder became moderate by ball milling for long time. The fine, moderate, and coarse $\mathrm{LiAlO}_{2}$ powders could pile up in the ceramic $\mathrm{LiAlO}_{2}$ powder in the natural state of the matrix by the process mentioned above. As seen from Figure 5, one piece of green sheet had a loose structure and a low bulk density. So that it could not withstand the gas penetration pressure between the anode and the cathode of the MCFC. Multiple green sheets were pressed together. It could compensate for the defect of a single green sheet. A dense matrix with a narrower distribution of pore size and a much higher bulk density was achieved.

3.4. Green Sheet Morphology. It had been demonstrated that the particle size distribution of ceramic powders had a great influence on the performance of slurry. Micro- or submicroceramic powders were usually considered to be favorable to obtain a stable suspension with high solid loading. High solid loading and low viscosity of $\mathrm{LiAlO}_{2}$ slurry were beneficial for casting during the matrix production process. Accordingly, it was important to maintain proper fluidity of the slurry by optimizing its solid loading. Figure 6 gives the morphologies of the green sheets with different solid loadings.

It could be seen that all the samples possessed homogeneous microstructure, but the samples showed apparent difference microstructures with the different solid loadings. The $\mathrm{LiAlO}_{2}$ particles were connected by polymer network formed by the binder and organic additives. The network was considered to be responsible for the favorable strength of green bodies. It is seen from Figure 6 that the $\mathrm{LiAlO}_{2}$ particles were basically wrapped with the binder and other organic additives, which filled in the space between $\mathrm{LiAlO}_{2}$ particles. The distance between the $\mathrm{LiAlO}_{2}$ particles became smaller and smaller with the increasing of solid loading and the sharp decreasing of solvent. As shown in Figures 6(a) and 6(b), a large distance between the particles could result in large holes in the matrix after organic ingredients burned up. Higher solid loading could reduce the distance between the particles, as verified in Figures 6(c) and 6(d). The particle size was the smallest and uniformly distributed, when the solid loading was $40 \%$. As the solid loading increased further, the slurry became thicker and pastier so that it was difficult to cast. Therefore, the slurry with $40 \%$ ceramic solid loading was better than the others. It could meet the requirements of the casting process.

3.5. Matrix Characterization. Based on the observations mentioned above, slurry composition with $40 \mathrm{wt} . \%$ ceramic powder was selected to produce the matrix for reasonable pore distribution and successful cell testing. The porosity and pore size distribution of the matrix were measured after burning out the organic ingredients in the matrix. The result of porosity analysis for the matrix is shown in Figure 7. The matrix had submicron pores in the range $0.1-0.4 \mu \mathrm{m}$ and a porosity of $50 \mathrm{vol} . \%$. It was consistent with the theoretical and technical requirements for the matrix.

To evaluate the matrix performance for gas sealing, a single MCFC was assembled. One matrix and two carbonate 


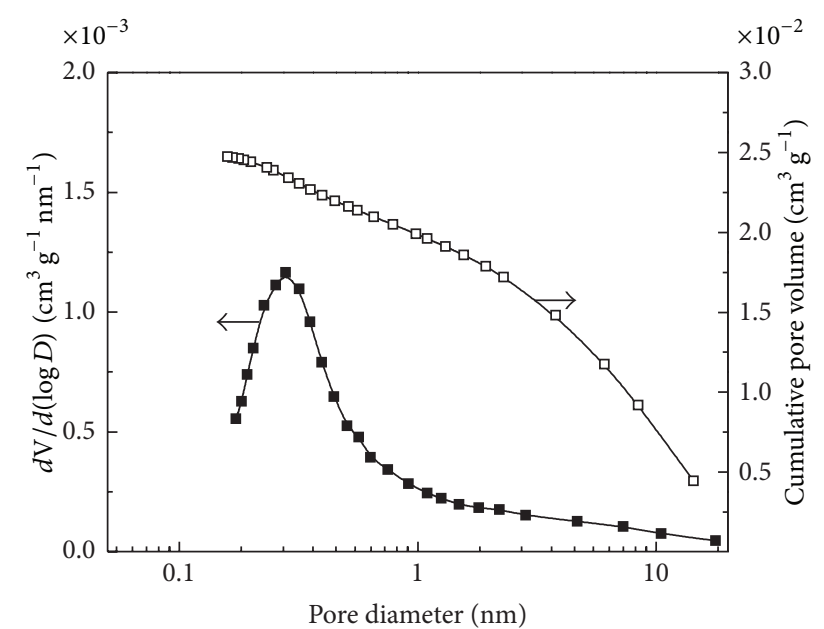

FIGURE 7: Pore size distribution of the matrix with $40 \%$ solid loading by the optimal process.

green sheets were stacked as a sandwich. Stainless steel end plates and the matrix with the carbonate sheets were assembled into a single cell. The matrix and the electrolyte sheets were sintered in situ under a specific heating program. The carbonates were molted at $480^{\circ} \mathrm{C}$ and immersed in the microholes in the matrix by capillary force. A measurement of gas crossover in the matrix was carried out when the temperature of $\mathrm{MCFC}$ rises to $540^{\circ} \mathrm{C}$. The cathode inlet and the anode outlet were closed, and the nitrogen pressure of the anode inlet was gradually increased to test the gas crossover. Gas crossover in the matrix occurred when gas was released from the cathode outlet. When pressure was under the pressure required for the measurement of gas crossover in the matrix, gas crossover occurred. The test result showed that the gas crossover occurred when the nitrogen pressure difference reached $0.7 \mathrm{MPa}$. It was indicated that the matrix with $40 \%$ solid loading had a good performance. When the cell temperature rose to $650^{\circ} \mathrm{C}$, if there was no gas crossover in the cell, the $\mathrm{H}_{2}$ was supplied to the anode, and a gas mixture of $70 \mathrm{~mol} \%$ air and $30 \mathrm{~mol} \%$ of $\mathrm{CO}_{2}$ was supplied to the cathode. The performance of the cell was tested by an electrochemical workstation. The results from electrical performance tests of the single cell were shown in Figure 8, where a maximum discharge current of $20 \mathrm{~A}$ at $0.56 \mathrm{~V}$ was used. The testing results demonstrated good performance of the matrix with $40 \%$ solid loading.

\section{Conclusion}

MCFC electrolyte matrices were prepared by tape casting. In order to optimise the production process of matrix, organic solvent, additives, and slurries with different solid loadings of lithium aluminate were used to prepare matrices green body. The result matrices green bodies were tested. Comparative results showed that particle size distribution of the slurries was determined by the solid loading amount and ball milling process. The slurry with $40 \%$ solid loading and ball milling condition of $450 \mathrm{rpm}$ for $24 \mathrm{~h}$ was optimal for matrix casting.

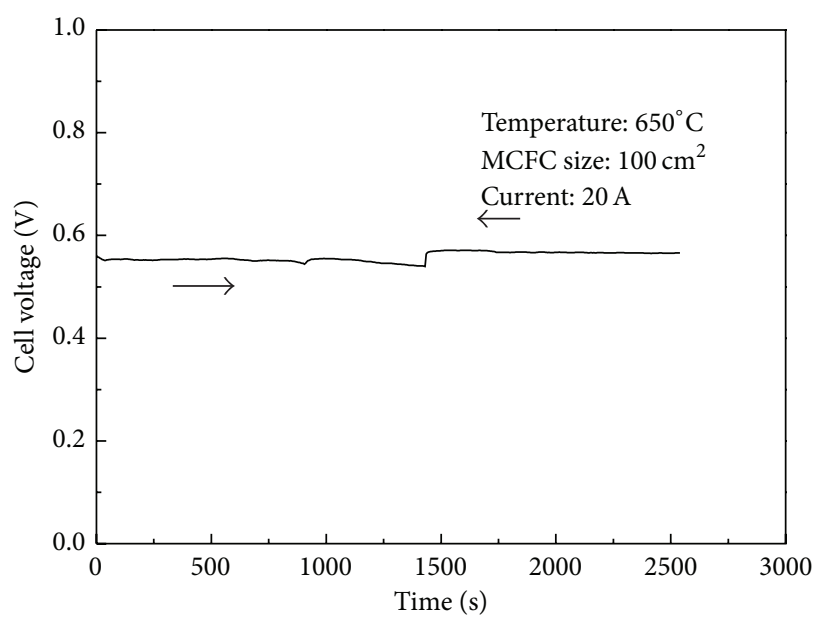

FIGURE 8: Discharging performance of a single MCFC with a matrix made of $\gamma-\mathrm{LiAlO}_{2}$ and $\alpha-\mathrm{LiAlO}_{2}$ powders.

Pore size distribution and electrical performance testing of the cell verified that the matrix prepared by the optimal process performed well for gas prevention and cell discharging in MCFC.

\section{Conflict of Interests}

The authors declare that they have no financial or personal relationships with other people or organizations that can inappropriately influence their work; there is no professional or other personal interest of any nature or kind in any product, service, and/or company that could be construed as influencing the position presented in or the review of this paper.

\section{Acknowledgment}

This study was supported financially by the National Energy Bureau Project of the integrated gasification fuel cell power generation system development and demonstration (NY20130202-1).

\section{References}

[1] J. Lee, H. Choi, S. Hyun, and H. Im, "Characteristics of aluminum-reinforced $\gamma$ - $\mathrm{LiAlO}_{2}$ matrices for molten carbonate fuel cells," Journal of Power Sources, vol. 179, no. 2, pp. 504-510, 2008.

[2] H. Lin, L. Zhou, and H. Zhang, "Sintering mechanism of porous matrix for molten carbonate fuel cell," Journal of Inorganic Materials, vol. 22, no. 4, pp. 759-764, 2007.

[3] L. Huaxin, Y. Baolian, Z. Li, H. Changqing, K. Lianying, and Z. Enjun, "A study on the performance of matrix prepared by tape cast and it s molten carbonate fuel cells (MCFCS)," Chinese Journal of Electrochemistry, vol. 6, no. 4, pp. 109-119, 2000.

[4] V. S. Batra, S. Maudgal, S. Bali, and P. K. Tewari, "Development of alpha lithium aluminate matrix for molten carbonate fuel cell," Journal of Power Sources, vol. 112, no. 1, pp. 322-325, 2002. 
[5] F. Yongfeng, C. Gang, and H. Keao, "Phase stability of MCFC electrolyte plate," Journal of Materials Science, vol. 17, pp. 76-78, 2003 (Chinese).

[6] I. Lee, W. Kim, Y. Moon, H. Lim, and D. Lee, "Influence of aluminum salt addition on in situ sintering of electrolyte matrices for molten carbonate fuel cells," Journal of Power Sources, vol. 101, no. 1, pp. 90-95, 2001.

[7] H. J. Byker, I. Eliezer, and N. Eliezer, "Hightemperature fuel cell research and development," Final Report for DOE Contract no. EC-77-C-03-1485, for period June 1977-September 1987.

[8] C.-G. Lee, H.-C. Lim, and J.-M. Oh, "Electrode reaction characteristics with slight pressure change in a molten carbonate fuel cell," Journal of Electroanalytical Chemistry, vol. 560, no. 1, pp. 1-11, 2003.

[9] H. X. Lin, B. L. Yi, and L. Zhou, "A study on the performance of matrix prepared by tape cast and its molten carbonate fuel cells," Electrochemistry, vol. 7, pp. 109-114, 2001.

[10] S. H. Hyun, S. C. Cho, J. Y. Cho, D. H. Ko, and S. A. Hong, "Reinforcement of molten carbonate fuel cell matrixes by adding rod-shaped $\gamma$ - $\mathrm{LiAlO}_{2}$ particles," Journal of Materials Science, vol. 36, no. 2, pp. 441-448, 2001.

[11] L. Shaochun, L. Dongyun, and Y. Hui, "Research progress in aqueous tape casting of ceramic materials," Chinese Journal of Materials Review, vol. 20, no. z2, pp. 387-389, 2006.

[12] C. Zhou, G. Li, and Y. Luo, "Effect of ball milling time on $\mathrm{Fe}_{2} \mathrm{O}_{3} / \mathrm{Al}$ nano-composite powder," Chinese Jomnul of Solid Rrocket Technology, vol. 33, no. 4, pp. 445-448, 2010.

[13] S. J. Pores, A. S. Nesaraj, P. R. Vadivel et al., "Preparation of electrolyte matrix structures by aqueous and non-aqueous tape casting method for molten carbonate fuel cells," Chinese Journal of Bulletin Electrochemistry, vol. 15, no. 9-10, pp. 400-403, 1999.

[14] C. Guohua, T. Linjiang, Z. Li, C. Jun, and L. Xinyu, "Fabrication and sintering substrate of CaAlSi system green tape by tapecasting for LTCC," Chinese Journal of Electronic Components and Materials, vol. 29, no. 8, pp. 18-21, 2010.

[15] M. P. Albano and L. B. Garrido, "Influence of the slip composition on the properties of tape-cast alumina substrates," Ceramics International, vol. 31, no. 1, pp. 57-66, 2005.

[16] H. Wu, S. Sang, W. Li, J. Pu, and J. Li, "SOFC anode support green tapes prepared by tape casting technique," Chinese Journal of Inorganic Materials, vol. 23, no. 1, pp. 82-86, 2008.

[17] T. H. Zhou, Q. H. Li, K. Y. Zheng, and J. Zhu, "Dispersant and ist application in the preparation of ceramics," Journal of Hubei University, vol. 23, no. 4, pp. 331-334, 2001. 

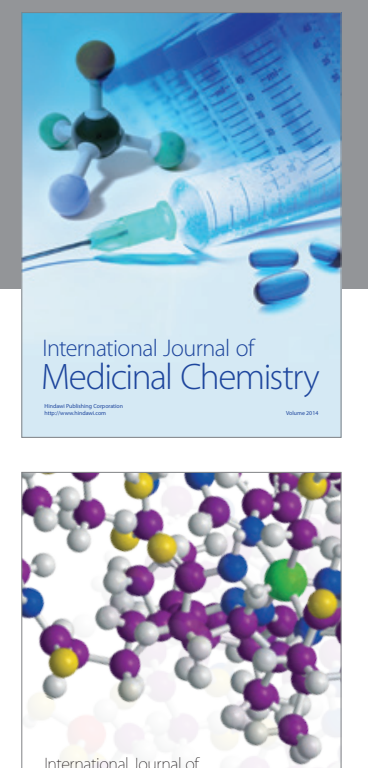

\section{Carbohydrate} Chemistry

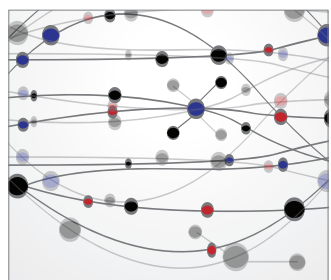

The Scientific World Journal
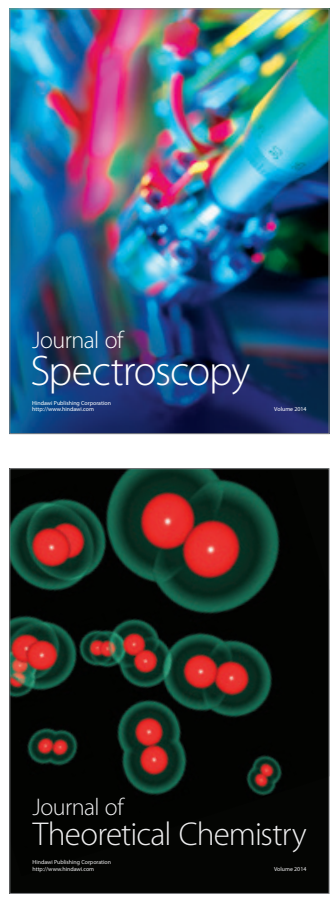
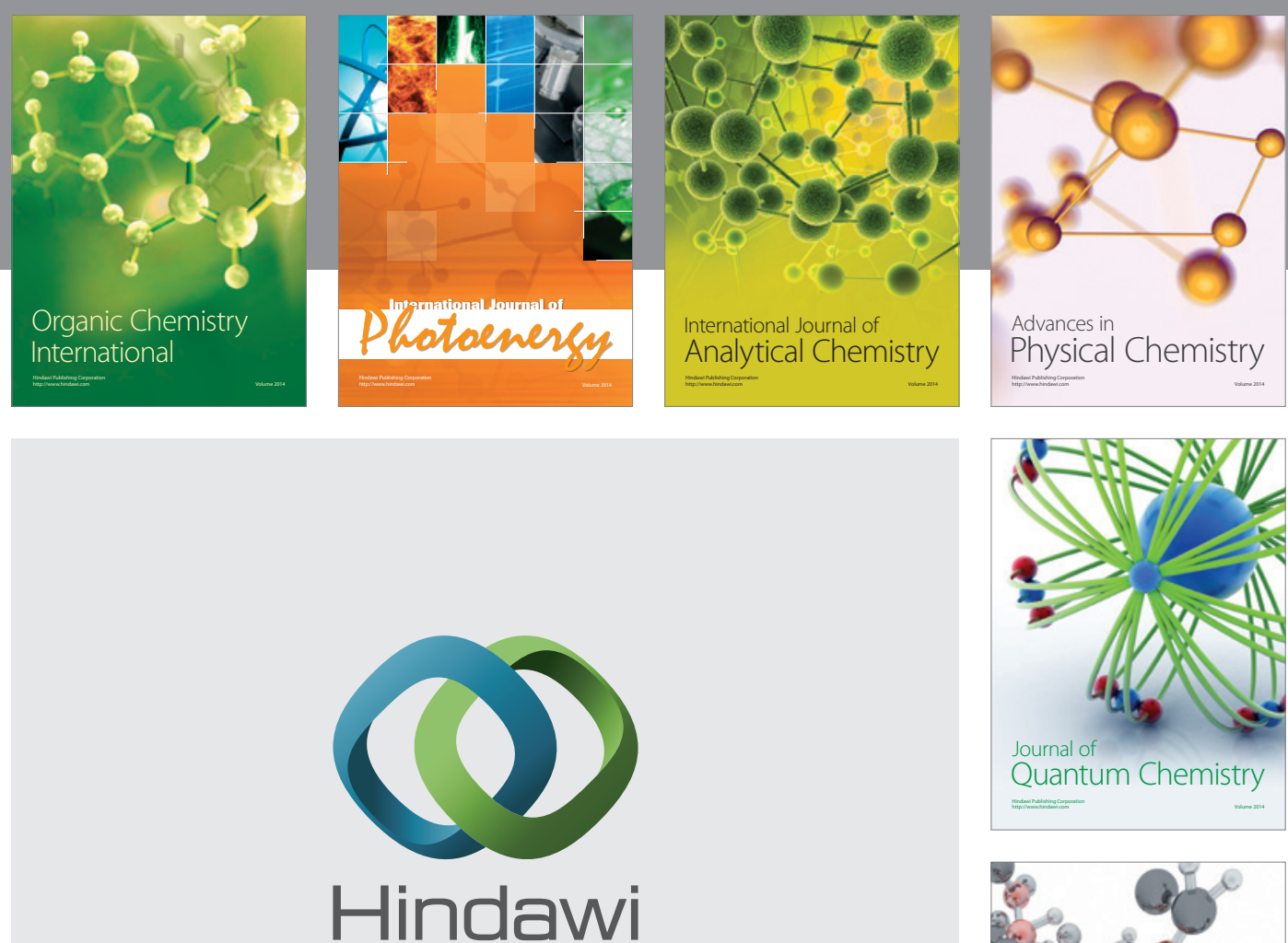

Submit your manuscripts at

http://www.hindawi.com

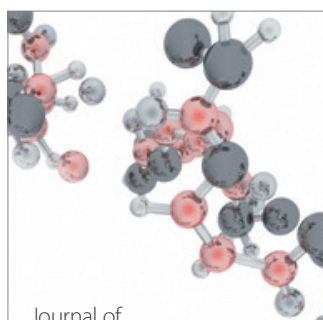

Analytical Methods

in Chemistry

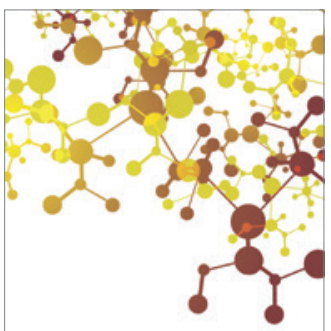

Journal of

Applied Chemistry

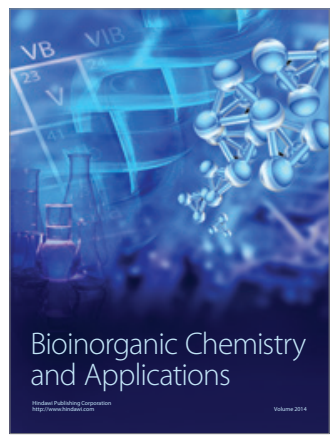

Inorganic Chemistry
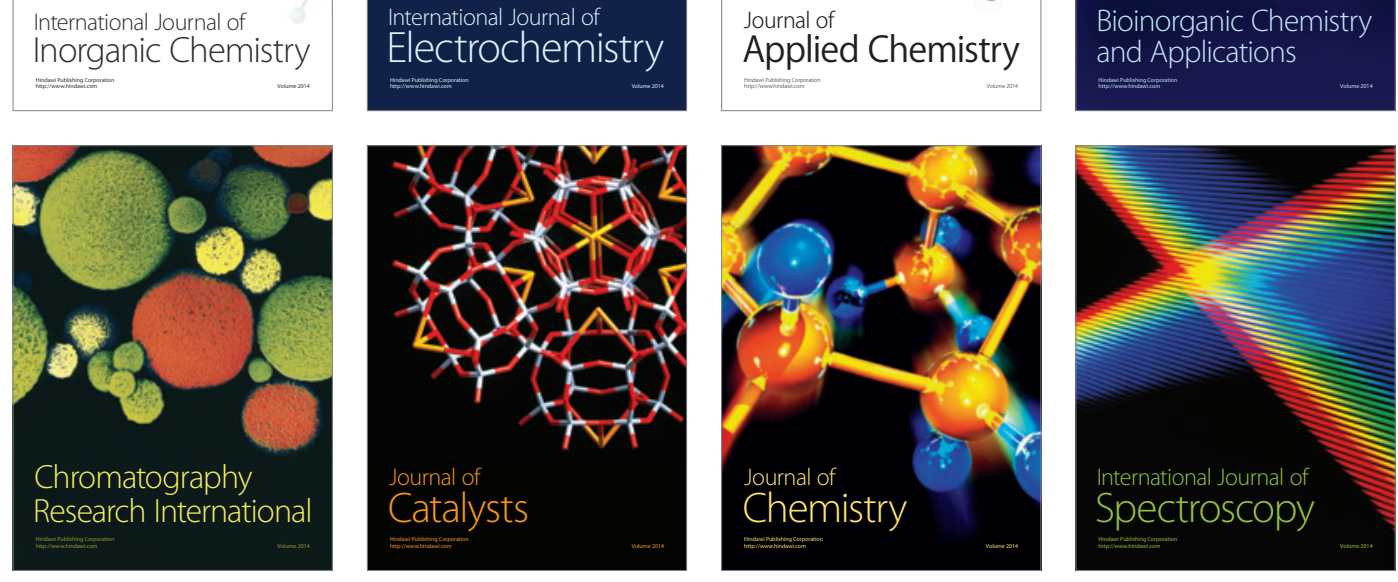